\begin{tabular}{lllllllllllllllll}
$\mathrm{S}$ & $\mathrm{T}$ & $\mathrm{U}$ & $\mathrm{D}$ & $\mathrm{I}$ & $\mathrm{A}$ & & $\mathrm{T}$ & $\mathrm{E}$ & $\mathrm{M}$ & $\mathrm{A}$ & $\mathrm{T}$ & $\mathrm{Y}$ & $\mathrm{C}$ & $\mathrm{Z}$ & $\mathrm{N}$ & $\mathrm{E}$ \\
\hline
\end{tabular}

STUDIA Z PRAWA WYZNANIOWEGO

Tom $21-2018$

DOI: https://doi.org/10.31743/spw.188

MICHAŁ HUCAŁ ${ }^{*}$

\title{
WYBRANE ZAGADNIENIA DOTYCZĄCE POZYCJI PRAWNEJ \\ DUCHOWNEGO W ORZECZNICTWIE EUROPEJSKIEGO TRYBUNAŁU PRAW CZŁOWIEKA
}

\section{Streszczenie}

Celem niniejszego artykułu jest zrekonstruowanie wybranych aspektów pozycji prawnej duchownego na gruncie orzecznictwa Europejskiego Trybunału Praw Człowieka. Analizie poddano 33 wyroki i decyzje w przedmiocie dopuszczalności skargi podjęte przez organy Europejskiej Konwencji Praw Człowieka w latach 1976-2017. Na ich podstawie można stwierdzić, że orzecznictwo ETPCz jest w tym zakresie ugruntowane wieloletnią praktyką.

Duchowny jako taki nie posiada gwarancji innych niż przysługujące każdej innej osobie wyznającej przekonania religijne, ale korzysta z pośredniego wzmocnienia tej ochrony dzięki gwarancjom korporacyjnej wolności sumienia i wyznania. To właśnie autonomia związku wyznaniowego dokonuje różnicowania jego pozycji tak pozytywnie, jak i negatywnie dla niego samego. Autonomia związku wyznaniowego jest bowiem w świetle orzecznictwa ETPCz istotnym komponentem pluralizmu w społeczeństwach demokratycznych, a należy do niej także określanie wymagań względem duchownych. $Z$ tego powodu duchowny uzyskuje silną ochronę przed ingerencją władzy państwowej w sprawy dotyczące jego powołania i usunięcia z urzędu. Kosztem uzyskania tej ochrony jest istotne ograniczenie jego osobistej wolności sumienia i wyznania, a pośrednio także innych praw w czasie pełnienia urzędu duchownego, w stosunku do związku wyznaniowego. Należy jednak pamiętać, że ocena spraw związanych z pełnieniem urzędu duchownego jest zależna od relacji ustrojowych między związkiem wyznaniowym i państwem. W przypadku kościołów państwowych możliwe jest np. poddanie pewnych spraw kościelnych orzecznictwu państwowemu, a związek wyznaniowy może dokonać swojego samoograniczenia kształtując relacje z duchownym na podstawie zwykłej

* Dr, Chrześcijańska Akademia Teologiczna w Warszawie, ul. Broniewskiego 48, 01-771 Warszawa, e-mail: michal.hucal@chat.edu.pl. ORCID 0000-0001-8446-0570. 
umowy o pracę. Co do zasady jednak ETPCz w sposób jasny wskazywał, że sprawy duchownych leżą poza jurysdykcją państwa i jego organów. Niemniej kontrowersje związane z orzekaniem w sprawie Károly Nagy v. Hungary wskazują, że status duchownego może ulegać pewnym zmianom w przyszłości.

Słowa kluczowe: prawa człowieka, duchowny, ETPCz; Europejski Trybunał Praw Człowieka; wolność sumienia i wyznania; związek wyznaniowy

$* * * * *$

WSTĘP

Europejski Trybunał Praw Człowieka (ETPCz) jest organem Konwencji o ochronie praw człowieka i podstawowych wolności ${ }^{1}$, zwanej także Europejską Konwencją Praw Człowieka (EKPCz), organem powołanym m.in. do rozstrzygania skarg osób na działania bądź zaniechania państw² Przedmiotem niniejszego artykułu są wybrane zagadnienia dotyczące pozycji prawnej duchownego w orzecznictwie Trybunału3 ${ }^{3}$. Wybór został podyktowany stopniem zaawansowania refleksji ETPCz dotyczącej poszczególnych elementów określających tę pozycję, w szczególności poprzez wskazanie jak postrzega on na gruncie Konwencji niektóre z uprawnień i obowiązków duchownego, w tym w porównaniu do innych osób. Tak w Konwencji, jak i w orzecznictwie nie wypracowano definicji osoby duchownej ${ }^{4}$, ale pośrednio można stwierdzić, że przez duchownego rozumie się na jej gruncie osobę powołaną przez związek wyznaniowy, wykonującą

1 Konwencja o ochronie praw człowieka i podstawowych wolności sporządzona w Rzymie dnia 4 listopada 1950 r., Dz. U. z 1993 r. Nr 61, poz. 284.

2 Por. Evans 2001, 69-72; Enea v. Italy [GC], nr 74912/01, orzeczenie Wielkiej Izby ETPCz z 17 września 2009 r., § 153. Por. także Igors Dmitrijevs v. Latvia, nr 61638/00, orzeczenie ETPCz z 30 listopada 2006 r. oraz Poltoratskiy v. Ukraine, nr 38812/97, orzeczenie ETPCz z 29 kwietnia 2003 r.

3 Należy zaznaczyć, że uwzględniony został także dorobek decyzyjny Europejskiej Komisji Praw Człowieka (EKomPCz), który wykorzystywany jest w orzekaniu przez sam ETPCz.

4 W przedmiocie prawa polskiego patrz: Mezglewski 2001, 3-26; Świto 2010, 41-50; Osuchowska 2011, 67-79. 
czynności z zakresu publicznego sprawowania kultu i nauczania w imieniu tego związku. Co istotne, ostateczną kwalifikację, czy pełnienie danej funkcji oraz sposób powołania uprawnia do uznania danej osoby za duchownego określa, co do zasady, autonomicznie i niezależnie sam związek wyznaniowy ${ }^{5}$. W związku z tym status duchownych należy rozpatrywać w kontekście gwarancji ochrony związków wyznaniowych, bowiem bez ich istnienia duchowny posiadałby te same prawa i obowiązki co każdy inny człowiek.

JURYSDYKCJA STRASBURSKA A ZWIĄZKI WYZNANIOWE

Celem Konwencji jest przede wszystkim ochrona jednostki przed nieuprawnionym wkroczeniem państwa w jej prawa i wolności ${ }^{6}$, ale także w ujęciu horyzontalnym, czyli w stosunku do osób trzecich w związku z zaniechaniem ochrony tych praw przez państwo. Przepis art. 9 Konwencji oprócz indywidualnej wolności myśli, sumienia i wyznania chroni również korporacyjną wolność sumienia i wyznania (,wspólnie z innymi”), w tym publiczne odprawianie nabożeństw, sprawowanie sakramentów i nauczanie kościelne. Ratio objęcia ochroną wspólnotowych form wyrażania przekonań religijnych jest związane z oczywistym faktem, że religia jest, co do zasady, zjawiskiem społecznym ${ }^{7}$, związanym ze wspólnym wykonywaniem kultu, a - z perspektywy historycznej - organizacje religijne są trwałymi formami ochrony uzewnętrzniania przekonań religijnych przed negatywnym wpływem państwa oraz osób trzecich. W tym miejscu należy podkreślić, że Konwencja dopuszcza jako uprawnione różne

5 Niemniej z uwagi na status prawny związku wyznaniowego może mieć na to wpływ także prawodawstwo państwowe (np. w przypadku kościołów państwowych); por. Hucał 2015, 41-46; Zieliński 2016, 290-298.

6 Art. 1 EKPCz: „Wysokie Układające się Strony zapewniają każdemu człowiekowi, podlegającemu ich jurysdykcji, prawa i wolności określone w Rozdziale I niniejszej Konwencji”; por. w kontekście indoktrynacji przez państwo: Warchałowski 2004, 121.

7 Por. kwestię określania, czy dane przekonania mają charakter religijny w kontekście istnienia bądź nie wspólnoty o takich przekonaniach religijnych: $X v$. the United Kingdom, nr 7291/75, decyzja o dopuszczalności skargi EKomPCz z 4 października 1977 r.; szerzej: Hucał 2012, 17-18; Evans 2001, 57-59; Warchałowski 2004, 93. 
modele prawnowyznaniowe - tak system rozdziału państwa i związków wyznaniowych ${ }^{8}$, jak i system powiązania, w tym istnienie w danym kraju kościoła państwowego lub narodowego9. Ochrona korporacyjnej wolności sumienia i wyznania w istotny sposób wpływa na pozycję prawną duchownego, przede wszystkim podporządkowując ją ochronie związku wyznaniowego, do czasu kiedy poddaje się dobrowolnie jego jurysdykcji jako osoba fizyczna.

Istnienie związków wyznaniowych - bez względu na stopień powiązania - ma wpływ także na postrzeganie ograniczeń wolności sumienia i wyznania przez Trybunał. Zauważył on, że art. 9 „,nie chroni każdego aktu motywowanego lub inspirowanego przez religię lub wierzenia"10, bowiem „W społeczeństwach demokratycznych, w których kilka religii koegzystuje wśród tej samej ludności, konieczne jest ustanawianie ograniczeń dla manifestowania religii lub wierzeń w celu pogodzenia interesów różnych grup i zapewnienia tego, aby szanowane były wierzenia wszystkich"11. Niemniej wprowadzając takie ograniczenia państwo powinno widzieć swoją rolę ,jako neutralnego oraz bezstronnego regulatora warunków, w których wyznawane są religia i przekonania religijne" ${ }^{2}$, bowiem ,sprzyja ona porządkowi publicznemu, harmonii religijnej oraz tolerancji w społeczeństwie demokratycznym"13. Ugruntowana linia orzecznicza ETPCz wskazuje, że niedopuszczalne są takie wkroczenia państwa w wolność sumienia i wyznania, które skutkują określaniem ,prawomocności przekonań religijnych lub sposobów w jakie są one wyrażane"14, jak również

8 Dogru v. France, nr 27058/05, orzeczenie ETPCz z 4 grudnia 2008 r., § 66 in fine, Refah Partisi (The Welfare Party) and Others v. Turkey nr 41340/98, 41342/98 i 41244/98, orzeczenie ETPCz z 31 lipca 2001 r., § 70, Leyla Şahin v. Turkey [GC], nr 44774/98, orzeczenie Wielkiej Izby ETPCz z 10 listopada 2005 r., § 114 oraz Dahlab v. Switzerland, no 42393/98, orzeczenie ETPCz z 25 lutego $2001 \mathrm{r}$.

9 Knudsen v. Norway, nr 11045/84, decyzja EKomPCz o dopuszczalności skargi z 8 marca 1985 r., Ahtinen v. Finland, nr 48907/99, orzeczenie ETPCz z 23 września 2008 r.; Darby v. Sweden, $n r$ 11581/85, decyzja EKomPCz o dopuszczalności skargi z 11 kwietnia 1988 r., § 45.

10 Leyla Şahin v. Turkey [GC], § 105 in fine.

11 Kokkinakis v. Greece, nr 14307/88, orzeczenie ETPCz z 25 maja 1993 r., § 33

12 Leyla Şahin v. Turkey [GC], § 106.

13 Tamże, $§ 107$.

14 Tamże, $\S 107$. 
działania zmierzające do wspierania lub kreowania nietolerancji między opozycyjnymi względem siebie grupami wyznaniowymi lub wewnątrzwyznaniowymi ${ }^{15}$. Z drugiej strony Konwencja zabrania także przymuszania grup wyznaniowych do wzajemnego uznawania się bądź łączenia, bowiem „rolą władz w takich okolicznościach nie jest usunięcie przyczyny napięć poprzez eliminowanie pluralizmu, lecz zapewnienie wzajemnej tolerancji między rywalizującymi grupami"16.

Te ogólne zasady odegrały istotną rolę w określaniu stopnia dopuszczalnego ograniczenia korporacyjnej wolności sumienia i wyznania, a tym samym statusu duchownych w poszczególnych związkach wyznaniowych. Zgodnie z orzecznictwem ETPCz autonomia związku wyznaniowego jest ,istotnym komponentem pluralizmu w społeczeństwach demokratycznych" ${ }^{17}$. Objęte są nią, co do zasady: określanie doktryny teologicznej oraz praktyki liturgicznej, jak i dyskurs teologiczny wewnątrz związku wyznaniowego; tworzenie struktury organizacyjnej i przyjmowanie prawa wewnętrznego ${ }^{18}$, w tym zasady włączania i wyłączania ze wspólnoty wiernych (pod warunkiem istnienia prawa do wystąpienia) ${ }^{19}$. Kluczowym elementem autonomii jest zakaz ingerowania w sprawy nawiązywania, zmiany oraz rozwiązywania stosunku służby kościelnej w stosunku do duchownych ${ }^{20}$.

\section{PRAWO DO PIASTOWANIA URZĘDU DUCHOWNEGO A INGERENCJA PAŃSTWA}

Fundamentem pozycji prawnej duchownego jest sama możliwość pełnienia urzędu duchownego w swoim związku wyznaniowym, na co składa się odpowiednie jego powołanie oraz uprawnienie wykonywania

15 United Communist Party of Turkey and Others v. Turkey [GC], nr 19392/92, orzeczenie Wielkiej Izby ETPCz z 30 stycznia 1998 r., § 57.

16 Leyla Şahin v. Turkey [GC], § 107.

17 Mirolubovs and Others v. Latvia, nr 798/05, orzeczenie ETPCz z 15 września 2009 r.

18 Warchałowski 2004, 261.

19 Holy Synod of the Bulgarian Orthodox Church (Metropolitan Inokenity) and Others v. Bulgaria, nr 412/03 i 35677/04, orzeczenie ETPCz z 22 stycznia 2009 r., § 141.

20 Nowicki 2010, 571. 
określonych funkcji religijnych. Orzecznictwo ETPCz wskazuje, że duchowny cieszy się, co do zasady, wolnością od ingerencją państwa w te procesy. Niemniej w określonych przypadkach może zaistnieć potrzeba wkroczenia państwa, gdy spór między osobami danego wyznania co do ich legitymacji jako przywódców religijnych wpływa na zewnętrzne prawa i obowiązki wspólnoty regulowane prawem powszechnie obowiązującym. Modelowym przykładem możliwości takiej interwencji jest sprawa Kohn v. Germany ${ }^{21}$, gdzie rola sądów państwowych ograniczyła się wyłącznie do uznania decyzji kompetentnych władz hamburskiej wyznaniowej gminy żydowskiej (sądu arbitrażowego przy radzie centralnej gmin wyznaniowych żydowskich) i nadania temu postanowieniu klauzuli wykonalności egzekucyjnej (kwestia dostępu do pomieszczeń, zasobów i dokumentów gminy). Zdecydowanie bardziej liczne są natomiast sprawy, w których Trybunał odniósł się krytycznie do rozstrzygania przez organy państwowe o skuteczności powołania lub odwołania duchownych ${ }^{22}$.

W sprawach Serif v. Greece ${ }^{23}$ oraz Agga v. Greece ${ }^{24}$, uznano, że penalizowanie wykonywania czynności kultowych oraz noszenia stroju przez duchownego, gdy państwo nie uznaje danego związku wyznaniowego lub legitymacji prawnej danych osób do reprezentowania wspólnoty religijnej stanowi naruszenie art. 9 Konwencji. Jak wskazuje na tej podstawie M.A. Nowicki, „nie da się uznać za zgodne z zasadami religijnego pluralizmu w demokratycznym społeczeństwie karania wyłącznie za pełnienie roli przywódcy religijnego grupy, która podporządkowała mu się z własnej woli"25. W sprawie Hasan and Chaush v. Bulgaria [GC] Trybunał wskazał, że ,wspólnoty religijne tradycyjnie i powszechnie istnieją w formie zorganizowanych struktur. Przestrzegają przy tym reguł, które są postrzegane przez wiernych często jako boskiego pochodzenia. Ceremonie religijne posiadają znaczenie oraz świętą wartość dla wierzących, jeśli są

${ }^{21}$ Kohn v. Germany, nr 47021/91, decyzja ETPCz o dopuszczalności skargi z 23 marca $2000 \mathrm{r}$.

22 Szerzej: Hucał 2012, 152-168, 177-184.

23 Serif v. Greece, nr 38178/97, orzeczenie ETPCz z 14 grudnia 1999 r.

24 Agga v. Greece (No 2), nr 50776/99 oraz nr 52912/99, orzeczenie ETPCz z dnia 17 października 2002 r.; Agga v. Greece (No 3), nr 32186/02, orzeczenie ETPCz z dnia 13 lipca 2006 r. oraz Agga v. Greece (No 4), nr 33331/02, orzeczenie ETPCz z dnia 13 lipca 2006 r.

25 Nowicki 2010, 574; por. Warchałowski 2004, 238. 
przeprowadzane przez duchownych powołanych do tego zgodnie z tymi regułami. Tożsamość duchownych jest bez wątpienia ważna dla każdego członka wspólnoty. Udział w życiu wspólnoty jest zatem manifestowaniem swojej religii, chronionym przez art. 9 Konwencji. Tam gdzie rozpatrywana jest sprawa organizacji wspólnoty religijnej, art. 9 powinien być interpretowany w świetle art. 11, który jest strażnikiem życia stowarzyszenia przed nieusprawiedliwioną ingerencją państwa. $Z$ tej perspektywy wolność sumienia i wyznania obejmuje oczekiwanie, że wspólnota będzie mogła funkcjonować pokojowo, wolna od arbitralnej interwencji państwa. $\mathrm{W}$ istocie autonomiczna egzystencja wspólnot religijnych jest niezbędna dla pluralizmu społeczeństwa demokratycznego i dlatego to zagadnienie należy do sedna ochrony z art. 9. (...) W przypadku braku ochrony przez art. 9 życia organizacyjnego wspólnoty, każdy z aspektów indywidualnej wolności sumienia i wyznania byłby niezabezpieczony przed atakiem"26. Trybunał podkreślił, że „działania państwa faworyzującego jednego z liderów frakcji danej wspólnoty religijnej lub zmuszające wspólnotę do zjednoczenia pod jednym przywództwem niezgodnie z jej własnymi życzeniami może oznaczać wkroczenie w wolność religii. W społeczeństwie demokratycznym państwo nie ma potrzeby podejmowania działań w celu zapewnienia jednolitego przywództwa dla wspólnot religijnych"27.

W innej bułgarskiej sprawie, tym razem dotyczącej podobnej ingerencji w sprawy prawosławia, Holy Synod of the Bulgarian Orthodox Church (Metropolitan Inokentiy) and Others v. Bulgaria, Trybunał zważył, że „tożsamość przywódców religijnych jest ważna dla członków wspólnoty religijnej. (...) Z tego powodu Trybunał uznaje, że art. 9 Konwencji, interpretowany w świetle art. 11, chroni prawo wiernych do wolności wyznania i zawiera w sobie oczekiwanie, że wspólnota będzie mogła funkcjonować wolna od arbitralnej interwencji państwa w jej organizację. Autonomiczne istnienie wspólnot religijnych jest niezbędne dla pluralizmu w społeczeństwie demokratycznym”28. Trybunał podkreślając, że „nie jest jego zadaniem określanie legitymacji kanonicznej przywódców kościelnych"29,

26 Hasan and Chaush v. Bulgaria [GC], § 62 .

27 Tamże, $§ 78$.

28 Holy Synod of the Bulgarian Orthodox Church..., § 103.

29 Tamże, $\S 104$. 
orzekł także, że Bułgaria w przedmiotowej sprawie przekroczyła granice neutralności aktywnie uczestnicząc w jednoczeniu Kościoła prawosławnego, w tym angażując do tego prokuraturę ${ }^{30}$, która „podjęła się zmuszenia wspólnoty do uznania jednego z dwóch rywalizujących przywódców oraz ograniczania działalności drugiego z nich" ${ }^{31}$. W kontekście tej sprawy I.C. Kamiński podkreśla, że legitymację do skargi do ETPCz mają w takich sprawach nie tylko przywódcy duchowni (zwierzchnicy związ$\mathrm{ku}$ ), ale także tzw. zwykli wyznawcy, więc tym bardziej tzw. zwykli duchowni Kościoła ${ }^{32}$.

\section{OGRANICZENIE PRAW DUCHOWNYCH WOBEC ICH ZWIĄZKU WYZNANIOWEGO}

Ochrona korporacyjnej wolności sumienia i wyznania, która wzmacnia ochronę indywidualnej wolności sumienia i wyznania duchownego wobec władz publicznych, znacząco osłabia jego pozycję w stosunku do władz związku wyznaniowego z uwagi na regułę szczególnej sytuacji (specific situation rule). Jak komentuje art. 9 L. Garlicki, „muszą oni akceptować zasady danej religii i reguły funkcjonowania kościoła. Uznaje się więc, że fakt przyjęcia stanowiska jest sam w sobie realizacją wolności wyznania i niejako pochłania inne aspekty tej wolności, zaś gwarancją ostateczną jest możliwość wystąpienia z kościoła lub założenia nowej grupy wyznaniowej"33.

W świetle orzecznictwa Komisji i Trybunału stwierdzić należy, że związki wyznaniowe mają wyłączne prawo do określania swoich procedur dyscyplinarnych, w tym kar, a od wyroków sądów dyscyplinarnych związku wyznaniowego lub innych uprawnionych organów wyznaniowych nie ma, co do zasady, odwołania do władz publicznych, w tym sądów państwowych. Oczywiście odpowiednie ukształtowanie prawa wewnętrznego lub publicznego może tę pozycję duchownego wzmocnić, np. poprzez

\footnotetext{
30 Tamże, § 107.

31 Tamże, $\S 139$.

32 Kamiński 2010 b, 36.

33 Garlicki 2010, 574.
} 
objęcie go kontraktem cywilnoprawnym (umowa o pracę) lub z uwagi na specyfikę kościoła państwowego. Niemniej również ukształtowanie stosunku prawnego z duchownym leży, co do zasady, w wyłącznej kompetencji związku wyznaniowego ${ }^{34}$. Pewnej ochrony duchowny może szukać w innych gwarancjach Konwencji, np. prawa do prywatności lub prawa do rzetelnego procesu sądowego, ale ochrona taka także jest osłabiona w związku z przyjęciem na siebie zobowiązań religijnych. Taka klarowna linia orzecznicza została ukształtowana nawet wobec świeckich pracowników kościelnych, gdy ich praca jest związana z etosem religijnym (np. wymóg misji kanonicznej) ${ }^{35}$.

Linia orzecznicza stwierdzająca, że duchowny realizuje swoją wolność sumienia i wyznania ostatecznie poprzez wystąpienie $\mathrm{z}$ danego związku wyznaniowego, liczy już cztery dekady. W 1976 r. w sprawie $X v$. Denmark stwierdzono, że art. 9 nie zawiera w sobie prawa duchownego - w tym przypadku państwowego Kościoła Danii - do określania warunków udzielania sakramentu niezgodnie z prawem kościelnym ${ }^{36}$. W sprawie przeciw Norwegii z 1984 r. uznano za pozbawioną podstaw skargę duchownego państwowego Kościoła ewangelicko-luterańskiego w Norwegii, usuniętego z urzędu duchownego w wyniku niewypełniania obowiązków administracyjno-kościelnych w ramach protestu przeciw ustawie o aborcji. W sprawie Karlsson v. Sweden negatywnie odniesiono się do możliwości istnienia uprawnienia do przyjmowania wyższych urzędów kościelnych w sytuacji, gdy związek wyznaniowy uznaje, że wymagana do tego jest lojalność wobec decyzji władz kościelnych (w tym przypadku uznawania ordynacji kobiet). Europejska Komisja Praw Człowieka wskazała wówczas, że ,,wolność religii nie zawiera w sobie prawa duchownego w ramach struktur Kościoła, w którym służy lub w którym ubiega się o urząd kościelny, do praktykowania odrębnych przekonań religijnych. (...) Jeśli wymagania stawiane przez kościół danej osobie stoją w konflikcie z przekonaniami tej osoby, powinna ona czuć się upoważniona do rezygnacji z urzędu kościelnego, a Komisja uznaje to za

34 Garnett 2010, 267.

35 Por. Travaš v. Croatia, nr 75581/13, orzeczenie ETPCz z 4 października 2016 r.

${ }^{36} X$ v. Denmark, nr 7374/76, decyzja EKomPCz o dopuszczalności skargi z 8 marca $1976 \mathrm{r}$. 
gwarancję jej wolności myśli, sumienia i wyznania"37. Takie stanowisko potwierdził także Trybunał w sprawie Williamson v. the United King$d \mathrm{~m}^{38}$, uznając że duchowny nie ma uprawnienia do kształtowania swojej odrębności w Kościele Anglii w sytuacji odmienności poglądów na temat ordynacji kobiet.

Organ Konwencji miał okazję odnieść się bezpośrednio do samych procedur dyscyplinarnych związków wyznaniowych jako postępowań cywilnoprawnych. W sprawie Tyler $v$. the United Kingdom ${ }^{39}$ duchowny Kościoła Anglii został pozbawiony urzędu kościelnego ze względu na cudzołóstwo. W związku z tym, że prawo Kościoła Anglii stanowi część prawa państwowego, a sądy kościelne stanowią część systemu sądownictwa Zjednoczonego Królestwa, Komisja zbadała, czy procedura spełnia wymagania art. 6 Konwencji, czyli prawa do rzetelnego procesu sądowego. Uznano, że niezależność instytucji dyscyplinarnych została przez kościół zapewniona poprzez zatrudnienie sędziów na stałe, ich minimum 7-letni okres doświadczenia prawniczego oraz składaną przez nich przysięgę. Należy przy tym pamiętać, że dopuszczenie do rozpatrywania sprawy pod kątem praworządności procesu dyscyplinarnego wynikało ze specyficznego położenia prawnego kościoła państwowego.

W systemach separacji duchowny może skarżyć pośrednio rozstrzygnięcie lub sposób jego dokonania przez instytucję wyznaniową z art. 6 Konwencji poprzez skargę na rozstrzygnięcie sądu powszechnego w przypadku odwołania się od skutków cywilnoprawnych decyzji wyznaniowej. Niemniej w przypadku nienadania przez związek wyznaniowy charakteru cywilnoprawnego służbie duchownego bądź rażącego naruszania innych praw człowieka, trudno znaleźć uzasadnienie dla dopuszczenia sprawy do rozpatrywania przez ETPCz. Ochrona duchownego jest zatem znacząco słabsza niż zwykłego pracownika na gruncie Konwencji. W sprawie Duda and Dudova v. the Czech Republic dotyczącej byłego już duchownego Czechosłowackiego Kościoła Husyckiego Trybunał uznał, że „istnienie

37 Karlsson v. Sweden, nr 12356/86, decyzja EKomPCz o dopuszczalności skargi z 8 września 1988 r.

38 Williamson v. the United Kingdom, decyzja EKomPCz o dopuszczalności skargi z 17 maja 1995 r.

39 Tyler v. the United Kingdom, nr 21283/93, decyzja EKomPCz z 5 kwietnia 1994 r. 
właściwości sądowej w sprawach takich jak kontynuowanie służby przez księdza w kościele byłoby sprzeczne z zasadą autonomii oraz niezależności związków wyznaniowych" ${ }^{40}$. Podobnie w sprawie Ahtinen v. Finland, w której duchowny dochodził swojego rzekomego prawa do uzyskania środka odwoławczego od decyzji przeniesienia do innej parafii, ETPCz nie podzielił ocen duchownego co do możliwości ingerowania w autonomiczne decyzje związku wyznaniowego.

W trzech podobnych do siebie sprawach z ostatnich lat dotyczących duchownych ewangelicko-unijnych kościołów krajowych, Baudler v. Germany ${ }^{41}$, Reuter v. Germany ${ }^{42}$ oraz Dietrich Reuter v. Germany ${ }^{43}$, Trybunał uznał za niedopuszczalne skargi na podstawie art. $6 \S 1$ Konwencji, związane z odmową przez sądy administracyjne orzekania w przedmiocie postępowań dyscyplinarnych duchownych. Duchowni zabiegali o tę ochronę argumentując, że nie skarżą rozstrzygnięć personalnych, lecz ich skutek finansowy - obniżenie uposażenia w wyniku odwołania z pełnienia stanowiska proboszcza lub przymusowego przejścia na wcześniejszą emeryturę. Dodatkowo starali się wykorzystać precedensowe orzeczenie Federalnego Trybunału Konstytucyjnego, który w 2003 r. stwierdził, że, o ile ocena sądowa zgodności z prawem kościelnym czynności związków wyznaniowych nie jest dopuszczalna, to meritum rozstrzygnięć dokonywanych przez nie może podlegać jurysdykcji sądowej w zakresie zgodności rozstrzygnięcia z fundamentalnymi zasadami porządku prawnego, w tym moralności publicznej czy porządku publicznego. ETPCz zaważył, że art. $6 \S 1$ stosuje się do postępowań cywilnych, gdzie roszczenie istnieje na gruncie krajowego prawa cywilnego, czego nie można powiedzieć o przedmiotowych sprawach. Co ciekawe, jednego ze skarżących duchownych w postępowaniu przed Trybunałem wspierał Związek Ewangelickich Duchownych Nadrenii.

40 Duda and Dudova v. the Czech Republic, nr 40224/98, decyzja ETPCz o dopuszczalności z 30 stycznia $2001 \mathrm{r}$.

${ }^{41}$ Baudler v. Germany, nr 38254/04, decyzja ETPCz o dopuszczalności skargi z 6 grudnia $2011 \mathrm{r}$.

42 Roland Reuter v. Germany, nr 39775/04, decyzja ETPCz o dopuszczalności skargi z 6 grudnia $2011 \mathrm{r}$.

43 Dietrich Reuter v. Germany, nr 32741/06 i 19568/09, decyzja ETPCz o dopuszczalności skargi z 17 stycznia 2012 r. 
W najnowszej sprawie, Károly Nagy v. Hungary ${ }^{44}$, pastor Węgierskiego Kościoła Reformowanego domagał się przed sądami powszechnymi odszkodowania z tytułu obniżenia mu przez kościelny sąd dyscyplinarny uposażenia z tytułu pełnienia urzędu duchownego, argumentując, że stosunek służby miał charakter cywilnoprawny. Sądy węgierskie konsekwentnie i zgodnie z orzecznictwem krajowego sądu konstytucyjnego pozostawiały sprawę bez nadania jej biegu, z uwagi na autonomię związku wyznaniowego wynikającą z obowiązującego w tym kraju systemu rozdziału ${ }^{45}$. Co istotne, Trybunał w tym przypadku nie uznał skargi za niedopuszczalną na podstawie art. $35 \S 3$ (a) Konwencji, bowiem charakter sprawy mógł posiadać cechy sporu cywilnoprawnego między kościołem a duchownym. Przyczyną potrzeby bliższego sprawdzenia natury tego stosunku był okólnik ministerstwa finansów Węgier, klasyfikujący uposażenie ze służby duchownego w kategorii dochodu $\mathrm{z}$ tytułu wynagrodzenia ${ }^{46}$. Trybunał zważył jednak ostatecznie, iż „w istocie takie roszczenia nie mogą być uznane za należące do uprawnień na gruncie prawa krajowego, a zatem ochrona z art. $6 \S 1$ nie ma zastosowania (...). Chociaż sąd konstytucyjny utrzymywał, że sądy państwowe nie mają jurysdykcji do badania roszczenia skarżącego, to w istocie tego dokonał [oceny merytorycznej roszczenia] w oparciu o regulacje umowy agencyjnej w świetle obowiązujących zasad krajowego prawa cywilnego. Zważył, że nie istnieje stosunek umowny między skarżącym i Kościołem kalwińskim. Ta decyzja nie może być uznana za stronniczą lub w sposób oczywisty nierozsądną. W tych okolicznościach skarżący nie może twierdzić, że został pozbawiony prawa do rozpoznania merytorycznego swojego roszczenia" 47 .

Należy zauważyć, że sprawa ta była niezwykle kontrowersyjna wśród sędziów orzekających w tej sprawie, wyrok zapadł większością jednego głosu, a w dołączonych oświadczeniach sędziów widać, że różnice opinii dotyczyły niemal każdej części orzeczenia. Część z nich domaga się rozpatrzenia sprawy przez Wielką Izbę ETPCz. Świadczyć to może o istniejącym ryzyku zmiany ugruntowanej zdawało się linii orzecznictwa w przypadku,

44 Kàroly Nagy v. Hungary, nr 56665/09, orzeczenie ETPCz z 1 grudnia 2015 r.

45 Tamże, $\S \S 6-15$.

46 Tamże, $\S \S 39-55$.

47 Tamże, $\S \S 73-75$. 
gdy organizacja służby duchownego przez związek wyznaniowy będzie konstruowana na podobieństwo kontraktu cywilnoprawnego. Dotyczy to zwłaszcza warunków materialnych służby, co do których władze publiczne mogą postępować niespójnie, szczególnie w sferze podatkowej. Oznaczałoby to jednak istotny wyłom w ochronie związków wyznaniowych, co wydaje się będzie prowadziło - podobnie jak w przypadku znanej sprawy Lautsi and Others v. Italy ${ }^{48}$ - do zachowawczego stanowiska Wielkiej Izby, czyli pozostania przy dotychczasowej linii orzeczniczej ${ }^{49}$.

Uznanie relacji między duchownym a związkiem wyznaniowym - podobnie jak patrząc szerzej relacji członek związku wyznaniowego i związek wyznaniowy - za leżącą w jurysdykcji państwa w sposób bezpośredni stanowiłoby ingerencję w sedno ochrony wolności sumienia i wyznania. Określanie bowiem statusu takich osób wpływałoby na określanie przez organy państwowe prawomocności przekonań religijnych pozostałych członków związku wyznaniowego, w zakresie czego państwo cieszy się niezwykle wąskim marginesem oceny. Rosnące spory w składach orzeczniczych ETPCz w tym zakresie mogą rodzić obawy, że brak skonkretyzowania zakresu ochrony wolności sumienia i wyznania może prowadzić pośrednio nawet do naruszenia sanctum sanctorum zakresu ochrony z art. 9, czyli tzw. forum internum ${ }^{50}$.

\section{PODSUMOWANIE}

Pozycja prawna duchownego na gruncie Konwencji jest zależna od ochrony autonomii związku wyznaniowego, jak również specyfiki praw-

48 Lautsi and Others v. Italy, nr 30814/06, orzeczenie Izby z 3 listopada 2009 r. oraz Lautsi and Others v. Italy [GC], nr 30814/06, orzeczenie Wielkiej Izby z 18 marca 2011 r.; por. wybrane glosy i literaturę w sprawie rozstrzygnięcia: Borecki, Pudzianowska 2010, 128; Brzozowski 2011, 121-126; Kamiński 2010 a, 40-47; Misztal, Stanisz 2010, 43; Zieliński 2012, 65-74.

49 Już po złożeniu niniejszej pracy do druku, Wielka Izba ETPCz rzeczywiście wydała orzeczenie w którym, stosunkiem 10 głosów do 7 i przy obszernych głosach odrębnych, uznała skargę za niedopuszczalną: Kàroly Nagy v. Hungary [GC], nr 56665/09, orzeczenie Wielkiej Izby ETPCz z 14 września 2017 r.

50 Petkoff 2012, 183-214. 
nowyznaniowej danego związku wyznaniowego. Duchowny sam z siebie nie posiada gwarancji innych niż przysługujące każdej osobie, ale korzysta ze wzmocnienia tej ochrony poprzez gwarancje korporacyjnej wolności sumienia i wyznania. Silna jest zatem ochrona przed ingerencją władzy państwowej w sprawy powołania i odwołania z urzędu duchownego. Kosztem uzyskania tej ochrony jest jednak - w stosunku do związku wyznaniowego - istotne ograniczenie jego osobistej wolności sumienia i wyznania, a pośrednio także innych praw w czasie pełnienia urzędu duchownego. Na gruncie Konwencji nie istnieje zatem roszczenie o powołanie na urząd duchowny wbrew decyzji związku wyznaniowego, jak również ochrona przed odwołaniem z niego przez wspólnotę. Również inne prawa, jak do rzetelnego procesu sądowego czy do prywatności, są w okresie pełnienia urzędu duchownego ograniczone z uwagi na ochronę autonomii związku wyznaniowego.

Należy jednak pamiętać, że ocena spraw związanych z pełnieniem urzędu duchownego jest zależna od ustrojowych zasad prawa wyznaniowego w danym kraju. Oprócz powiązania państwa i związku wyznaniowego wpływać na to może także odpowiednie ukształtowanie stosunku prawnego między duchownym a związkiem wyznaniowym, jak również ocena tego stosunku lub jego elementów przez organy publiczne (np. podatkowe). W takich sprawach może dochodzić do badania zaniechania przez państwo ingerencji w działalność związku wyznaniowego, ale nadal trudno wyobrazić sobie rozstrzygnięcie dotyczące samej kwestii uznania czyjegoś prawa bądź nie do pełnienia urzędu. Niemniej sprawa Károly Nagy v. Hungary wskazuje, że temat zaczyna budzić dyskusje na łonie ETPCz, co jest zjawiskiem nowym.

\section{BIBLIOGRAFIA}

Borecki, Paweł, Dorota Pudzianowska. 2010. „Glosa do wyroku z 3 XI 2009 w sprawie Lautsi v. Włochy, skarga nr 30814/06”. Państwo i Prawo 4: 124-129.

Brzozowski, Wojciech. 2011, „Glosa do wyroku Wielkiej Izby z 18 III 2011 w sprawie Lautsi v. Włochy, nr skargi 30814/06". Państwo i Prawo 11: 121-126. Evans, Carolyn. 2001. Freedom of Religion under the European Convention on Human Rights. Oxford: Oxford University Press. 
Garlicki, Lech (red.). 2010. Konwencja o Ochronie Praw Człowieka i Podstawowych Wolności. Tom I. Komentarz do artykułów 1-18. Warszawa: C.H. Beck.

Garnett, Richard W. 2010. „Religious Liberty, Church Autonomy, and the Structure of Freedom". W: Christianity and Human Rights. An Introduction, red. John Witte Jr. and Frank S. Alexander. Cambridge: Cambridge University Press.

Hucał, Michał. 2012. Ochrona wolności sumienia $i$ wyznania w orzecznictwie Europejskiego Trybunatu Praw Człowieka. Warszawa: C.H. Beck.

Hucał, Michał. 2015. Oddziaływanie brytyjskiej ustawy o prawach człowieka z 1998 r. na Kościót Anglii. Toruń: Wyd. Adam Marszałek.

Kamiński, Ireneusz C. 2010 a. „Nakaz obecności krzyża we włoskiej szkole - glosa do wyroku ETPCz z 3.11.2009 w sprawie Lautsi v. Włochom”. Europejski Przeglad Sadowy 3: 40-47.

Kamiński, Ireneusz C. 2010 b. „Wolność myśli, sumienia i wyznania w orzecznictwie ETPCz za lata 2008-2009”. Europejski Przeglad Sądowy 11: 33-39.

Mezglewski, Artur. 2001. „Pojęcie duchownego w przepisach prawa polskiego o zawieraniu małżeństwa". Studia z Prawa Wyznaniowego 2: 3-26.

Misztal, Henryk, Piotr Stanisz. 2010. „Wolność wyznania a symbole religijne w życiu publicznym państwa świeckiego". Annales Canonici 6: 37-55.

Nowicki, Marek Antoni. 2010. Wokót Konwencji Europejskiej. Komentarz do Europejskiej Konwencji Praw Człowieka. Kraków: Wolters Kluwer.

Osuchowska, Marta. 2011. „Pojęcie duchownego w świetle przepisów o wyznaniowej formie zawarcia małżeństwa cywilnego". Państwo i Prawo 7-8: 67-79.

Petkoff, Peter. 2012. „Forum Internum and Forum Externum in Canon Law and Public International Law with a Particular Reference to the Jurisprudence of the European Court of Human Rights". Religion \& Human Rights 7, no 3: 183-214.

Świto, Lucjan 2010. „Charakter prawny posługi duszpasterskiej proboszczów i wikariuszy w parafiach rzymskokatolickich w świetle prawa polskiego". Seminare 27: 41-50.

Warchałowski, Krzysztof 2004. Prawo do wolności myśli, sumienia i religii w Europejskiej Konwencji Praw Człowieka i Podstawowych Wolności. Lublin: Towarzystwo Naukowe KUL.

Zieliński, Tadeusz J. 2012. „Zakaz indoktrynacji światopoglądowej w szkolnictwie według wyroku Lautsi przeciwko Włochom". W: Prawne granice wolności sumienia $i$ wyznania, red. Roman Wieruszewski, Mirosław Wyrzykowski, Lena Kondratiewa-Bryzik. Warszawa: Wolters Kluwer.

Zieliński, Tadeusz J. 2016. Państwowy Kościół Anglii. Studium prawa wyznaniowego. Warszawa: Wyd. Naukowe ChAT. 


\title{
SELECTED ISSUES REGARDING THE LEGAL POSITION OF THE RELIGIOUS MINISTER IN THE CASE LAW OF THE EUROPEAN COURT OF HUMAN RIGHTS
}

\author{
Summary
}

The research goal is to reconstruct selected aspects of the legal position of the religious minister on the basis of the case law of the European Court of Human Rights. The analysis includes 33 judgments and decisions on the admissibility of complaints made by the bodies of the European Convention on Human Rights in 1976-2017. Based on them, it can be concluded that the ECtHR case law in this area is grounded in many years of practice.

The religious minister as such has no guarantees other than those of any other person professing religious beliefs, but he benefits from the indirect strengthening of this protection by virtue of the guarantees of corporate freedom of conscience and religion. It is the autonomy of a religious organization that differentiates his position in both positive and negative respects. The autonomy of a religious organization is, in the light of ECtHR jurisprudence, an important component of pluralism in democratic societies, and it also includes determining the requirements for the religious minister. For this reason, the religious minister obtains strong protection against the interference of state power in matters relating to his appointment and removal from the office. The cost of obtaining this protection is a significant limitation of his personal freedom of conscience and religion, and indirectly also other rights while in the office of a priest, in relation to a religious organization. However, it should be remembered that the assessment of matters related to the performance of the office of a priest depends on the formal relations between a religious organization and the state. In the case of state churches, it is possible, for example, to submit certain church matters to state jurisprudence, and a religious organization can perform its self-limitation by shaping relations with the religious minister on the basis of a regular employment contract. As a rule, however, the ECtHR clearly indicated that matters concerning the religious minister lie outside the jurisdiction of the state and its organs. Nevertheless, the controversy surrounding the ruling in Károly Nagy v. Hungary indicates that the religious minister's status may undergo some changes in the future.

Key words: human rights; religious minister; ECtHR; European Court of Human Rights; freedom of conscience and religion; religious organization 